\title{
CONJUNCTIVAL KERATOACANTHOMA
}

Fernanda Braga Perdigão, Paulo de Tarso P. Pierre-Filho, Renato José Mendonça Natalino, Roberto Caldato, Marcelo Torigoe and Maria Letícia Cintra

PERDIGÃO FB et al. Conjunctival keratoacanthoma. Rev. Hosp. Clín. Fac. Med. S. Paulo 59(3):135-137, 2004.

Keratoacanthoma generally occurs on the skin; it is rarely found in the conjunctiva. A case of a 34-year-old woman with a rapidly growing conjunctival mass is reported. The tumor was excised with a safety margin to exclude squamous cell carcinoma. Histopathologically it was crateriform and consistent with atypical keratoacanthoma. There has been no recurrence in 2 years of follow-up. Conjunctival keratoacanthoma is rare; differential diagnosis of conventional squamous cell carcinoma and keratoacanthoma can be difficult. We recommend complete surgical excision and careful follow-up of crateriform squamous proliferations.

KEYWORDS: Conjunctival keratoacanthoma. Squamous cell carcinoma. Tumor. Histopathology. Conjunctiva.

Keratoacanthoma (KA) is a relatively common benign tumor on exposed skin areas. It is characterized by rapid growth (4-8 weeks) and may regress spontaneously. There are only 15 reported cases related to the conjunctiva ${ }^{1-4}$. We describe a case of conjunctival KA and discuss the clinical and pathological findings.

\section{CASE REPORT}

A 34-year-old white female hospital cleaner was seen by the ophthalmologist because of a six-week-old rapidly growing conjunctival mass in her right eye. She occasionally felt a foreign-body sensation. Biomicroscopic examination revealed a white nodular mass with a central hyperkeratotic area on the right eye nasal conjunctiva (Fig. 1). It measured $15 \times 15$ $\mathrm{x} 20 \mathrm{~mm}$ and was surrounded by dilated episcleral vessels. The lesion was promptly excised with a safety margin. It was confined to the conjunctiva and the underlying sclera was left bare.

Histopathological examination showed a crater-shaped epithelial neoplasm containing keratin (Fig. 2). The neoplasm cells were atypical with a moderate number of mitoses. They were glassy with abundant eosinophilic cytoplasm (Fig. 3). A lichenoid mononuclear infiltrate was seen in several areas. Normal conjunctival epithelium was observed at the resected edges. An initial differential pathological diagnosis of conjunctival $\mathrm{KA}$ and squamous cell carcinoma (SCC) was performed.

From the Departments of Ophthalmology and Pathology of the State University of Campinas (UNICAMP) - Campinas/SP, Brazil.

E-mail: fernandaperdigao@yahoo.com.br Received for publication on October 30, 2003.
There was no recurrence of lesion 2 years after surgery.

\section{DISCUSSION}

Keratoacanthoma (KA) is a squamous epithelial neoplasm characterized by the rapid growth of a painless, firm keratotic nodule. It is known to regress without treatment, however tumors are usually excised as they are hard to distinguish from conventional well differentiated squamous cell carcinoma (SCC) or because they may become malignant. The first case of conjunctival KA was described by Freeman et al. ${ }^{5}$ in 1961 . Only 15 cases have been described to date ${ }^{4}$.

The pathogenesis of KA remains unknown. Exposure to carcinogens, sunlight, trauma, and viral infection have not been confirmed ${ }^{6}$.

As characteristically observed in KA, our patient's lesion grew rapidly; 


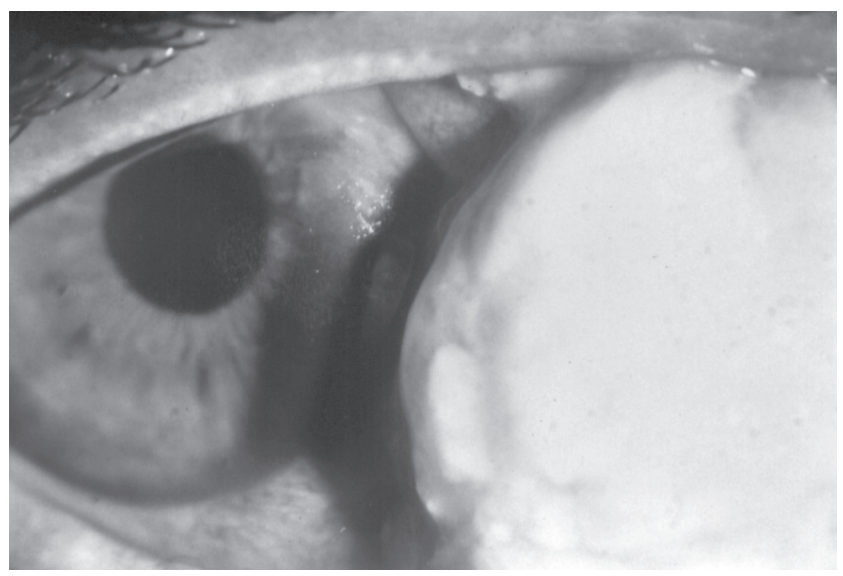

Figure 1 - Conjunctival keratoacanthoma of the right eye revealing a nodular, elevated, white conjunctival mass situated at the perilimbic nasal conjunctiva.

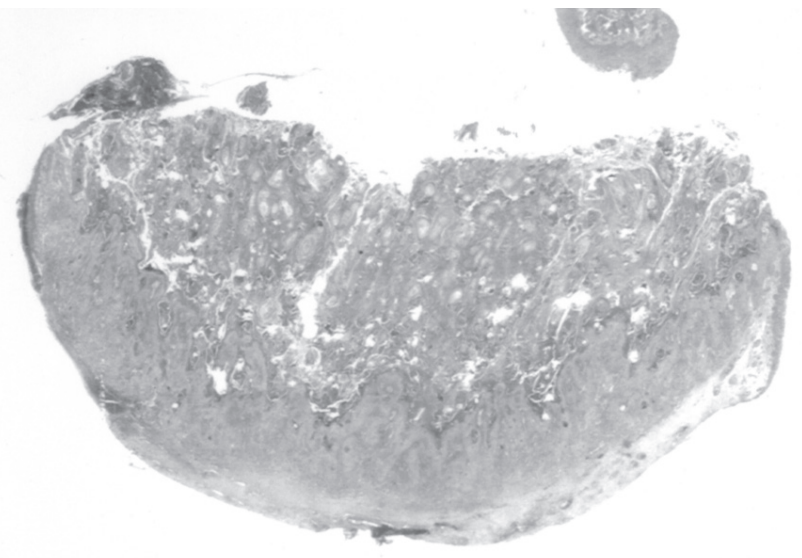

Figure 2 - Excised specimen showing a cup shaped configuration of acanthotic squamous epithelium with keratin in the crater (hematoxylin and eosin, $\mathrm{x} 10$ ).

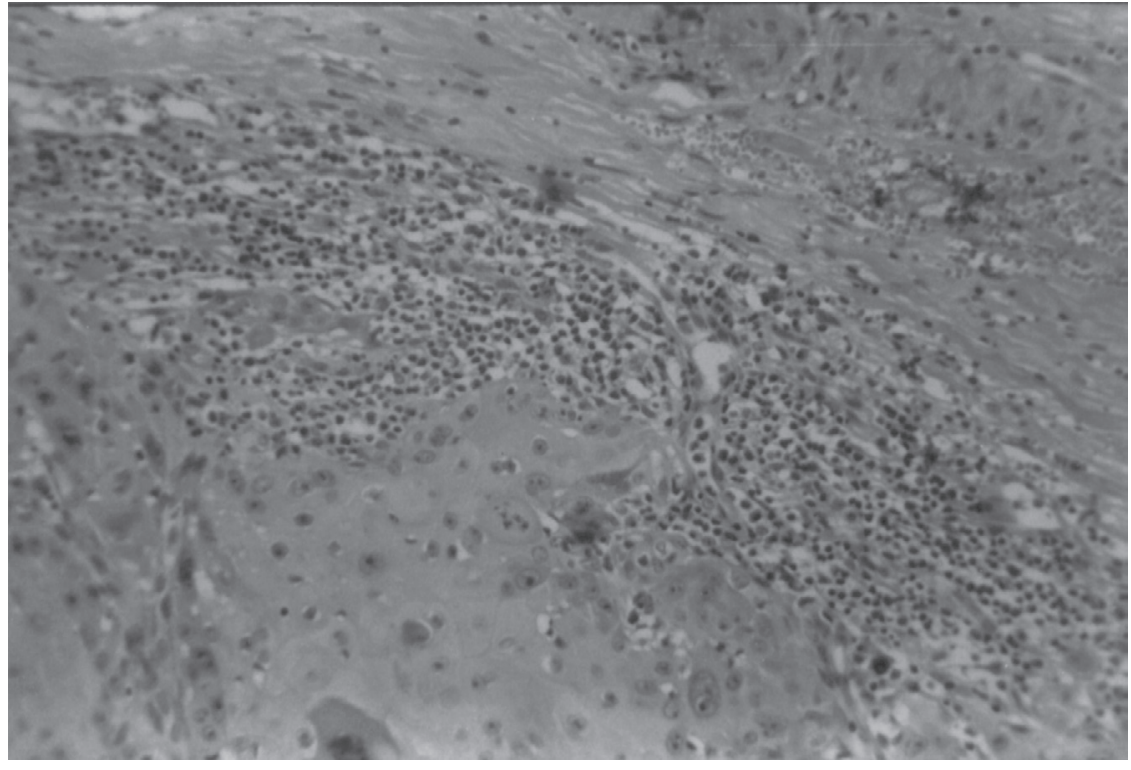

Figure 3 - Aspect showing eosinophilic glassy-appearing atypical cytoplasm and a moderate number of mitoses (hematoxylin and eosin, x 100).

it was removed as it could have progressed to malignancy. The main differential diagnosis is conventional SCC, which occurs more frequently than KA. Symptom duration in SCC is usually more than 2 months, but may be less than 1 week ${ }^{7}$. Conjunctival KA preferentially occurs in the limbic region, which is similar to SCC. The KA lesion occurs more frequently at the temporal limbus 6 , but in our patient it occurred at the nasal limbus.
At first, our patient's lesion was considered a SCC by the examining pathologist. It had typical crateriform architecture with large, glassy keratinocytes and a mononuclear lichenoid infiltrate at the base. However, nuclei pleomorphism was evident, probably due to the fact that the lesion was very young. KAs can easily be mistaken for SCC as clinical presentation and histopathologic findings are very similar. Some authors regard KA as a variant of $\mathrm{SCC}^{8}$. Others believe they are different since Kas, as a group, display unique clinico-pathological features. The clinical features and histological architecture in our patient were consistent with keratoacanthoma. Surgical removal was justified because of possible eventual malignancy ${ }^{9}$ and the difficulty of clinically differentiating this lesion from squamous cell carcinoma.

After complete excision, careful follow-up is important for all patients with conjunctival keratoacanthoma.

\section{RESUMO}

Perdigão FB e col. Ceratoacantoma conjuntival. Rev. Hosp. Clín. Fac. Med. S. Paulo 59(3):135-137, 2004.
Ceratoacantoma geralmente ocorre na pele e raramente é encontrado na conjuntiva. Relatamos um caso de uma mulher de 34 anos que apresen- tou uma massa conjuntival de rápido crescimento. O tumor foi retirado com margem de segurança para excluir carcinoma de células escamosas. Ao exa- 
me histopatológico, o tumor apresentou configuração crateriforme, sendo consistente com ceratoacantoma atípico. Não houve recorrência após dois anos de seguimento. Ceratoacantoma conjuntival é uma doença rara. Um di- agnóstico diferencial entre carcinoma de células escamosas e ceratoacantoma pode ser difícil. Recomendamos total remoção e seguimento cuidadoso de pacientes com lesões escamosas crateriformes.
UNITERMOS: Ceratoacantoma conjuntival. Carcinoma de células escamosas. Tumor. Histopatologia. Conjuntiva.

\section{REFERENCES}

1. Kifuku K, Yoshikawa H, Sonoda KH, Kawano Y, Miyazaki K, Ishibashi T. Conjunctival keratoacanthoma in an Asian. Arch Ophthalmol 2003;121:118-9.

2. Coupland SE, Heimann H, Kellner U, Bornfeld N, Foerster MH, Lee WR. Keratoacanthoma of the bulbar conjunctiva. Br J Ophthalmol 1998;82:586.

3. Munro S, Brownstein S, Liddy B. Conjunctival Keratoacanthoma. Am J Ophthalmol 1993;116:654-5.

4. Hughes EH, Intzedy L, Dick AD, Tole DM. Keratoacanthoma of the conjunctiva. Eye 2003;17:781-2.

5. Freeman RG, Cloud TM, Knox JM. Keratoacanthoma of the conjunctiva. A case report. Arch Ophthalmol 1961;65:817-9.
6. Tulvatana W, Pisarnkorskul P, Wannakrairot P. Solitary keratoacanthoma of the conjunctiva: report a case. J Med Assoc Thai 2001;84:1059-64.

7. Mckelvie PA, Daniell M, Mcnab A, Loughnan M, Santamaria JD. Squamous cell carcinoma of the conjunctiva: a series of 26 cases. Br J Ophthalmol 2002; 86:168-73.

8. Hodak E, Jones RE, Ackerman AB. Solitary keratoacanthoma is a squamous cell carcinoma: three examples with metastases. Am J Dermatopathol 1993; 15:332-42

9. Sanchez Yus E, Simon P, Requena L, Ambrojo P, de Eusebio E. Solitary keratoacanthoma: a self-healing proliferation that frequently becomes malignant. Am J Dermatopathol 2000; 22:305-10. 